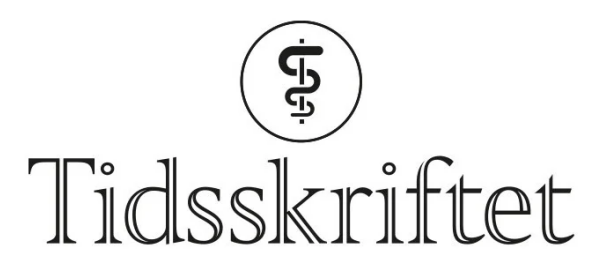

DEN NORSKE LEGEFORENING

\title{
Kvantitativt måtehold
}

TIDLIGERE I TIDSSKRIFTET

JULIE DIDRIKSEN

Tidsskriftet

«Alle» er interessert i ernæring hos barn, men interessen for hva de eldste blant oss burde spise har vært liten, ifølge en artikkel i Tidsskriftet nr. 4/1917. Under følger en rekke forslag om hva de burde spise - og en advarsel om at gamle matvaner er vonde å vende (Tidsskr Nor Lægeforen 1917; 15: 131-2).

Strauss: Om ernæring i oldingealderen. I motsætning til ernæringen i barnealderen, som opviser en hel literatur, har interessen for ernæring $\mathrm{i}$ involutionsperioden været meget liten. Der er imidlertid mange eiendommelige tilstande, som særtegner oldingealderen, og som er værd at ta hensyn til. Bortset fra de slet ikke likegyldige defekter i tandgaren er det især følgende tilstande, som fortjener vor opmerksomhet: Stasekatarrer, svind av mavevæggens tykkelse og formindskelse av dens kjertelorganer - særlig pepsinkjærtlerne; og disse mangler gjør, at man maa undgaa tungt fordøielige spiser. Nedsættelse av mavesaftsekretionen, svind av fettet $i$ bukhulen og enteroptosen er andre vigtige senile faktorer. - Derimot holder mavesækkens motilitet sig godt helt til den høie alderdom. 


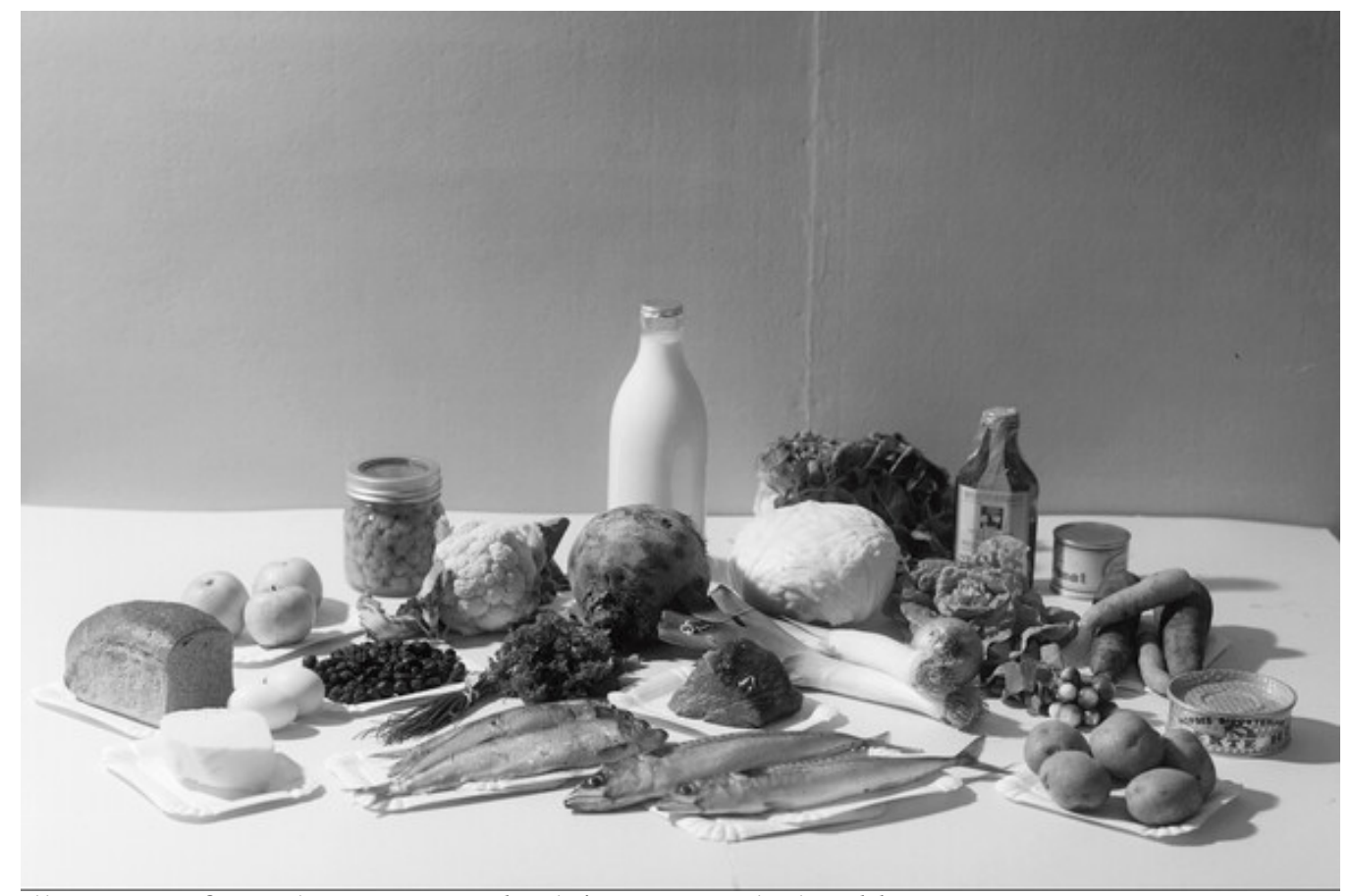

Illustrasjonsfoto: Christian Grundseth / Anno Domkirkeodden

Tarmen er hos oldingen ikke istand til at kompensere manglerne ved fødens bearbeidelse i munden og mavesækken, væggene blir tynde, slimhinden og muskularis atrofisk. Den væsentlige aarsak til træg mave hos oldinger er leieforandringer og muskelsvækkelse i tyktarmen. Nedsættelse av sensibiliteten i rektum kan ogsaa være aarsak til koprostasen.

Endelig vil ogsaa svækkelse av bukpressen og hæmorrider vanskeliggjøre defækastionen. Forstyrrelser av hjertets funktion bevirker ofte en særlig ømfindtlighet for enhver sterkere opfyldning av maven, idet diafragma derved drives op og bevirker en leieforandring av hjertet med indskrænkning av dets bevægelighetsfrihet.

Det vilde imidlertid ikke være rigtig at opstille noget bestemt skema for ernæring av oldinger paa grundlag av de nævnte senile forandringer. Gamle folk opgir nødig sine vaner, selv om de er til skade. Man maa derfor ikke tvinge sine fordringer igjennem, naar forandringer i diæeten ikke er absolut nødvendig. Man fremkalder bare ulyst paa mat og gjør ingen nytte. Altsaa ingen smaalige diætforskrifter, men bare almene mere eller mindre strengt forordnende, alt eftersom tilfældet fordrer det.

\section{«Gamle folk opgir nødig sine vaner, selv om de er til skade»}

For det første: Maten maa ikke kræve en altfor intensiv tygning, men skal ha en mere flytende eller grøtagtig konsistens. Mængden bør bare utgjøre omtrent $3 / 4$ av, hvad et i arbeidsperioden værende menneske behøver. Næringen bør ikke indeholde meget av de stoffer, som kan danne rikelig gas, fordi opdrivning av tarmene let foraarsaker oppressionstilstande. Grundsætningen maa være: «Faa og hyppigere maaltider.» En olding maa altid faa sin anden frokost og «eftasværd». Heldigst vil det være, om melk og melkemat dannet hovednærings midlet - dertil hvetebrød og kjeks, kavringer osv. Men en olding maa ogsaa ha et visst kvantum av kjøt, helst hvitt (høns, kalv osv.).

Raa frugt bør forbydes, men eple- og aprikoskompot er gunstig; likeledes godt kokte plommer. Spørsmaalet om nydelsesmidler blir besvart noget forskjellig av forskjellige læger. Naar en gammel mand hele sit liv har drukket $1 \frac{1}{2} \mathrm{fl}$. vin pr. dag, skal man ikke forbyde ham den apetit- og humørforbedrer. Et glas vin eller en liten snaps er et fortræffelig «mavemiddel» for mange gamle folk. - Derimot maa en rikelig nydelse av alkohol forbydes, særlig koncentrerte alkoholsorter (het vin, kognak o. s. v.). 
Det samme gjælder for bruken av tobak. Lette cigarer vil neppe skade en, som er vant til at røke tobak, mere end det tvungne avhold fra et tilvant nydelsesmiddel. Personer, som maa ligge til sengs, maa faa en anden ernæring og i andre mængder end den, som endnu kan ta tilstrækkelig motion.

Angaaeende grundsætningen for diæten i oldingealderen gjelder et ord av Naunyn: «Kvantitativt maatehold er i almindelighet hovedsaken.» Diæten skal ikke reguleres efter et givet skema, men efter bestemte grundsætninger.

Publisert: 28. august 2020. Tidsskr Nor Legeforen. DOI: 10.4045/tidsskr.20.0121

(C) Tidsskrift for Den norske legeforening 2023. Lastet ned fra tidsskriftet.no 26. april 2023. 